\title{
KARAKTERISTIK NON-HARMONIK PASANG SURUT DI PERAIRAN SEKITAR KOTA BITUNG
}

\author{
(Non-Harmonic Characteristics of Tides Around Bitung Waters)
}

\author{
Jalaluddin Hamzah $^{{ }^{*}}$, Royke M. Rampengan ${ }^{1}$, Agung B. Windarto ${ }^{1}$ \\ 1. Program Studi IImu Kelautan Fakultas Perikanan dan IImu Kelautan Universitas Sam \\ Ratulangi, Manado \\ *e-mail : ijalhamzah82@gmail.com
}

Non-harmonic analysis is a method applied to directly correlate the tidal period and the tide height with moon phase and astronomical parameters. Two main parameters determined of the sea level data recording were tide range and its period. Other variables considered was mean sea level. The highest tide range occurred in spring tide, and the lowest in the neap tide. The highest and the lowest mean range occurred in January to June. The lowest mean sea level occurred in 1987 and the highest in 2010, indicating that the mean sea level of Bitung waters has risen.

Keywords: tide, non-harmonic, tide range, sea level.

Analisis non-harmonik merupakan metode yang diaplikasikan dengan cara secara langsung menghubungkan waktu terjadi pasang dan surut air laut serta ketinggiannya dengan fase umur bulan dan parameter-parameter astronomis. Dua variabel utama yang dideterminasi dari pencatatan data muka laut adalah tunggang pasang surut dan periodenya. Variabel lain turut diperhitungkan adalah muka laut rata-rata. Tunggang pasang surut yang terbesar terjadi pada saat fase umur bulan purnama. sedangkan tunggang pasang surut terkecil terjadi pada saat fase umur bulan perbani. Rata-rata tunggang pasang surut terbesar dan terkecil terjadi pada semester awal. Muka laut rata-rata pada tahun 1987 di periaran Kota Bitung merupakan muka laut rata-rata yang terendah bila dibandingkan dengan tahun 2010 yang merupakan muka laut rata-rata paling tertinggi, mengindikasikan muka laut rata-rata tahunan pada perairan sekitar Kota Bitung mengalami kenaikan.

Kata kunci : pasang surut, non-harmonik, tunggang pasut, muka laut

\section{PENDAHULUAN}

Daerah pantai Kota Bitung merupakan ruang yang sangat intensif dimamfaatkan. Secara aktual, dapat dijumpai berbagai fasilitas seperti pemukiman, bangunan pelindung pantai, pabrik pengalengan ikan dan tentunya pelabuhan laut.

Menurut Losada et al. (2010) dalam dekade terakhir pemanfaatan laut dan sumber daya di dalamnya yang tidak memperhatikan unsur keberlanjutan adalah penyebab terjadinya kemerosotan progresif dari sistem di ruang dekat pantai. Lebih lanjut dijelaskan oleh Hwung (2010) hal ini juga yang menjadi penyebab mengapa informasi yang berhubungan dengan lingkungan sangat diperlukan saat akan dilakukan rencana pengembangan lingkungan pantai. Menurutnya, kondisi-kondisi lingkungan yang dimaksud antara lain kondisi oseanografi.

Menurut Stewart

oseanografi adalah studi tentang lautan dengan penekanan pada karakteristik lingkungannya untuk memperoleh deskripsi kuantitatif secukupnya yang akan digunakan memprediksi kondisi yang akan datang dengan cukup akurat. Sedangkan oseanografi fisik adalah studi tentang karakteristik fisik dan dinamik lautan. Salah satu bagian yang dibicarakan dalam ilmu oseanografi, khususnya oseanografi fisik adalah pasang-surut (pasut). Pasut merupakan fenomena alam mengenai permukaan perairan seperti lautan yang berubah-ubah tunggang (range) dan 
ketinggiannya sesuai dengan perubahan posisi bulan dan matahari terhadap bumi menurut fungsi waktu (Lisnawati et al., 2013). Thorpe (2009) mengungkapkan metode dasar yang dikembangkan dalam hubungannya dengan analisis untuk mengungkapkan karakteristik pasut salah satunya adalah metode non-harmonik. Metode yang dilakukan secara langsung menghubungkan waktu terjadinya air pasang dan surut dengan fase dari Bulan dan beberapa parameter astronomis.

Dua variabel utama pasut yang dideterminasi dari pencatatan data muka laut adalah tunggang pasut (tidal range) dan periodenya. Tunggang pasut merupakan beda tinggi antara level air tinggi dan rendah yang mengikutinya, sedangkan periode adalah waktu antara satu air tinggi (atau air rendah) dan air tinggi (atau air rendah) berikutnya (Pugh and Woodworth, 2014). Variabel lain yang umumnya turut diperhitungkan dalam analisis non-harmonik adalah rata-rata muka laut (mean sea level).Muka laut rata-rata (disingkat MLR atau dalam bahasa Inggris MSL) umumnya dinyatakan dalam bentuk MLR harian, bulanan, tahunan, atau untuk periode lebih panjang.

Adapun tujuan dari penelitian ini adalah mendeskripsikan fluktuasi tunggang air pasut dan duduk tengah muka laut dengan fase umur bulan dan beberapa parameter astronomis lainnya.

\section{METODE PENELITIAN}

Penelitian ini dilakukan pada tahun 2017 dengan memanfaatkan data pengukuran pasut yang diukur oleh Badan Meteorologi, Klimatologi, dan Geofika (BMKG) Kota Bitung dari tahun 1987 sampai tahun 2011. Namun, data pengukuran yang digunakan terdapat data pada tahuntahun tertentu tidak dilakukan pengukuran dan di tahun yang lain, banyak kehilangan data pengukuran (error). Penelitian mengenai karakteristik non-harmonik pasang surut di perairan sekitar Kota Bitung ini, dilakukan dengan menempuh beberapa tahapan yaitu :

\section{Penataan Data}

Data hasil pengukuran pasut dimasukkan ke dalam bentuk tabel dengan format diurutkan menurut tanggal dan jam pengukuran.

2. Pengolahan Data

Pengolahan data diawali dengan menggambar grafik pasut dari data pasut terukur. Kegiatan ini dilakukan dengan tujuan untuk memudahkan menentukan waktu terjadinya pasang dan surut dan mempermudah perhitungan periode. Sebelum data diubah dalam bentuk grafik, terlebih dahulu diurutkan data pasut dihari tertentu dengan data pasut hari berikutnya.

3. Penambangan Data Astronomis

Penambangan data astronomis berupa jarak antara bulan dan bumi, jarak bumi dan matahari, dan fase umur bulan dilakukan dengan bantuan perangkat lunakstellarium.

4. Pencarian muka laut rata-rata

Pencarian muka laut rata-rata dilaksanakan dengan menggunakan metode $X_{0}$ atau metode filter Doodson. Metode ini mempunyai batasan waktu (t) yaitu $-19<\mathrm{t}>19$. Metode filter Doodson adalah sebagai berikut :

$$
X_{T}=\frac{1}{30} \sum_{d=-19}^{d=19} F(d) H(T+d), d \neq 0
$$

Dimana :

$\mathrm{H}(\mathrm{t})$ : Elevasi Muka Laut

$\mathrm{F}(\mathrm{d}): 2,1,1,2,0,1,1,0,2,0,1,1,0,1,0,0,1,0$, T: Jam 12 siang

\section{HASIL DAN PEMBAHASAN}

\section{Tunggang Pasut}

Tunggang pasut merupakan selisi antara pasang tertingi dan surut terendah yang mengikutinya. Tunggang pasut dideterminasi melalui perbedaan tinggi elevasi pasut tertinggi dengan elevasi pasut terendah berikutnya. Tunggang pasut berbeda menurut fase 
umur bulan. Telaah mengenai tunggang pasut harian dapat dicermati melalui periode terjadinya pasang dan surut setiap hari. Gambar-gambar berikut ini menampilkan fluktuasi perubahan elevasi pasut pada fasefase umur bulan tertentu, yaitu saat bulan baru (new moon), perbani awal (first quarter), bulan penuh (full moon), dan kuartir akhir (third quarter). Gambar 1 sampai Gambar 4 memperlihatkan fluktuasi muka laut pada 4 fase umur bulan yang utama. Kedua data yang dipilih untuk ditampilkan bertolak dari kejadian awal fase umur bulan baru yang berbeda.

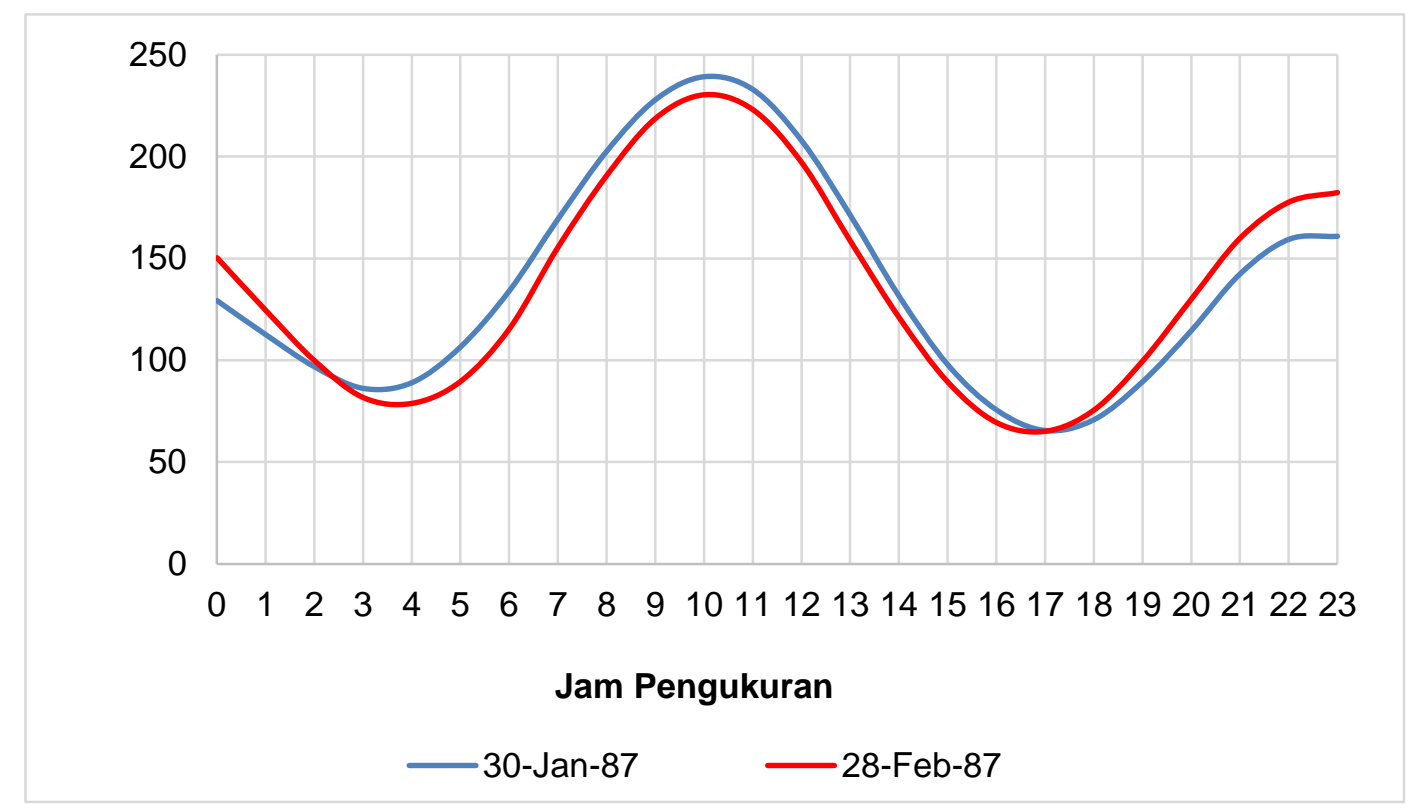

Gambar 1. Fluktuasi elevasi muka laut pada fase umur bulan baru.

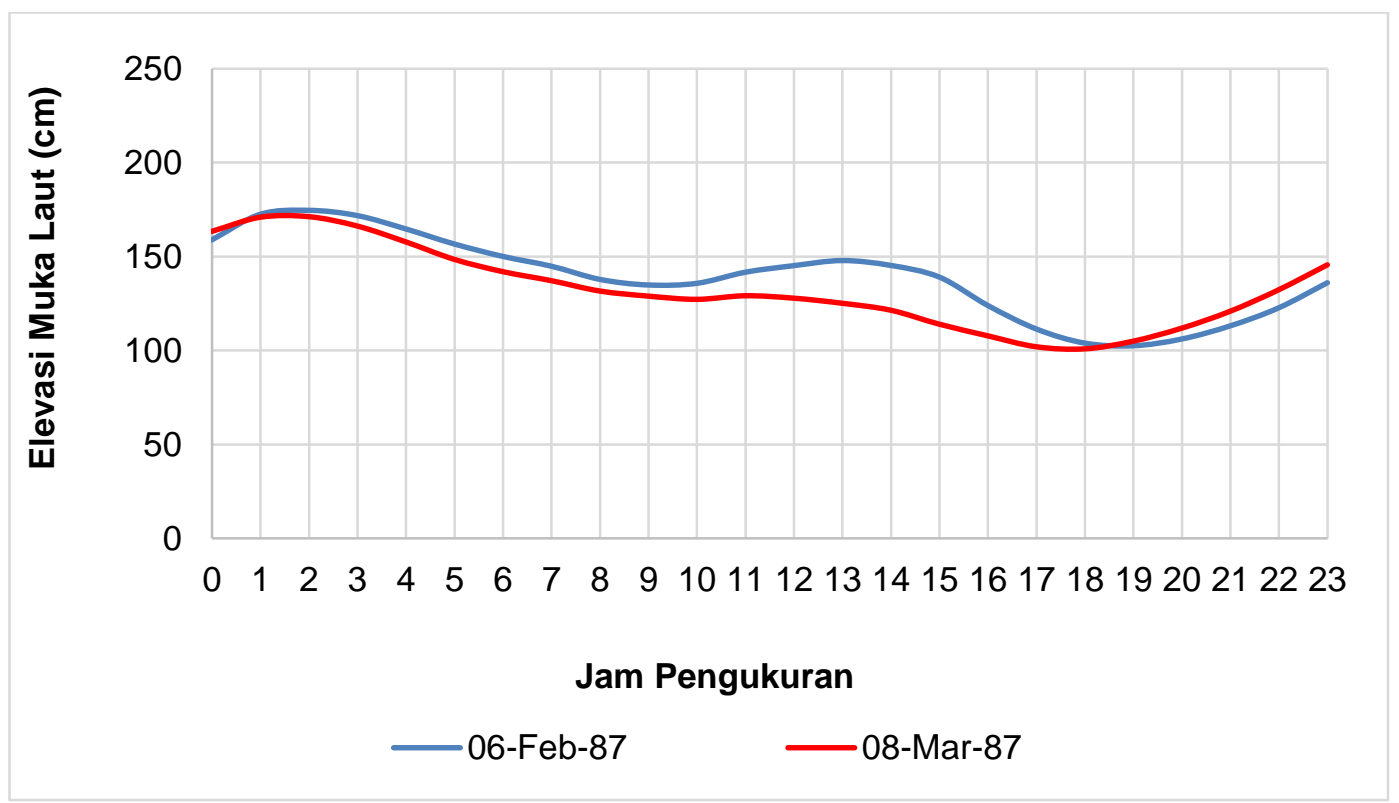

Gambar 2. Fluktuasi muka laut pada fase umur bulan perbani awal. 


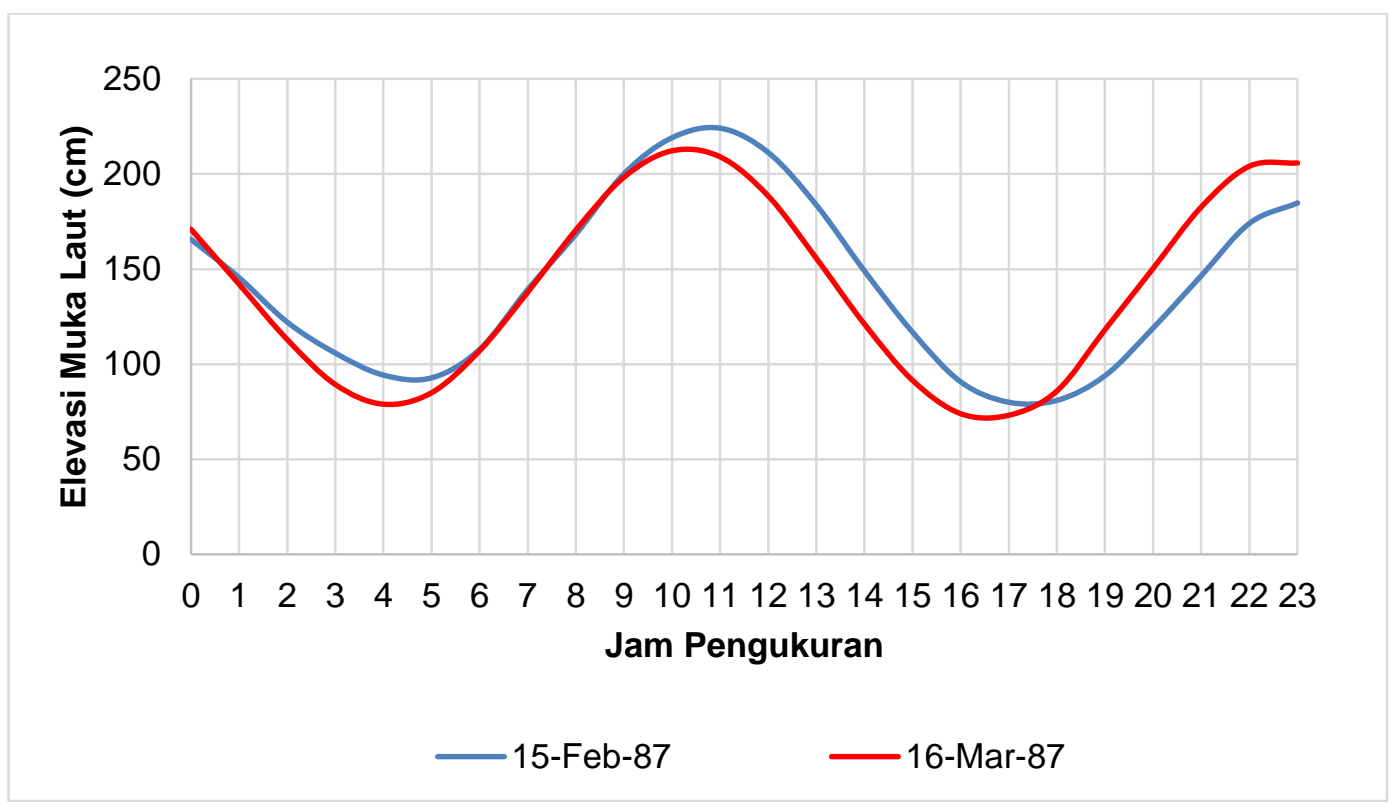

Gambar 3. Fluktuasi muka laut pada fase umur bulan penuh (Purnama).

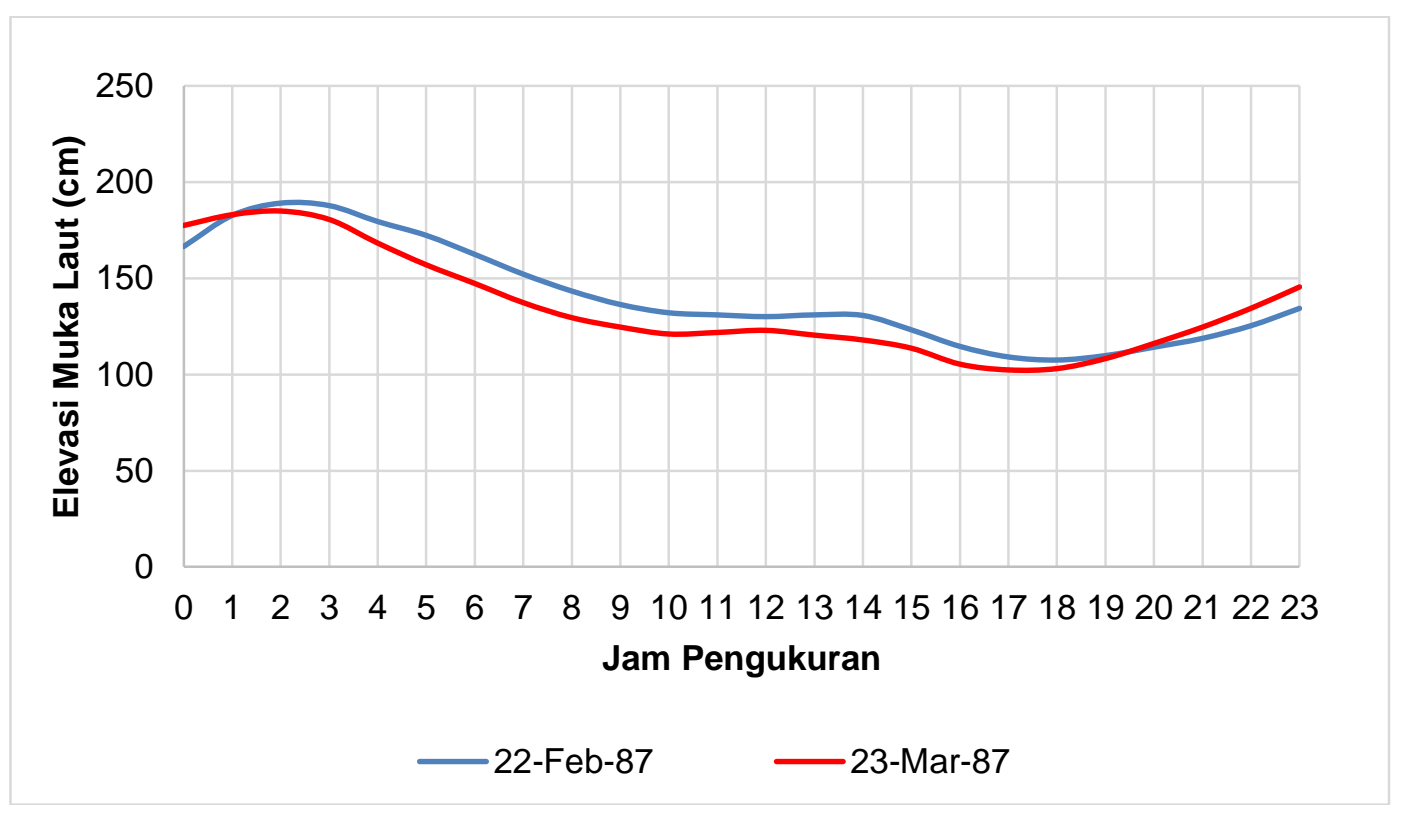

Gambar 4. Fluktuasi muka laut pada fase umur bulan perbani akhir.

Berdasarkan gambar-gambar tersebut, dapat dilihat bahwa waktu terjadinya pasang tertinggi dan surut terendah pada perairan sekitar Kota Bitung ini terjadi dalam waktu yang hampir sama, sekalipun bertolak dari waktu awal terjadinya bulan baru yang berbeda. Saat terjadinya pasang purnama (spring tide) yaitu pada fase bulan baru dan bulan penuh, surut terendah pertama terjadi sekitar jam
04.00 dan pasang tertinggi yang mengikutinya terjadi sekitar jam 10.00. Surut terendah berikutnya terjadi pada sore hari sekitar jam 17.00 kemudian air mulai bergerak naik kembali. Saat umur bulan perbani, baik perbani awal maupun perbani akhir, pasang tertinggi pertama terjadi sekitar jam 02.00 dan kemudian air mulai surut mencapai minimumnya pada sekitar jam 10.00. Kemudian air sedikit bergerak naik 
sekitar 1 sampai 3 jam berikutnya, dan kembali bergerak turun mencapai minimumnya pada sekitar jam 17.00 atau 18.00 kemudian air bergerak naik kembali.

Berdasarkan kurva fluktuasi elevasi muka laut, terutama yang terjadi saat pasang purnama, dapat dilihat bahwa tipe pasut pada perairan ini bertipe campuran condong ke harian ganda. Pada tipe pasut ini saat pasang purnama akan tampak jelas terlihat dalam sehari terjadi dua kali pasang dan dua kali surut dengan elevasi yang tidak sama. Hal ini bersesuaian dengan yang disampaikan oleh Wirtky dalam Pariwono (1989) mengenai tipetipe pasut di perairan Indonesia. Perairan sekitar Semenanjung Minahasa, baik yang berhadapan dengan Laut Sulawesi maupun Laut Maluku, tipe pasutnya tergolong pada tipe pasut campuran condong ke harian ganda.

Berdasarkan keempat gambar tersebut, juga dapat dilihat perbedaan tunggang pasut yang terjadi saat pasangpurnama (fase umur bulan baru dan bulan penuh) dengan tunggang pasut yang terjadi saat pasang perbani. Tunggang pasut saat pasang purnama lebih besar dibandingkan dengan tunggang pasut saat perbani. Hal ini bersesuaian dengan teoritisnya, saat pasang purnama posisi bulan, bumi, dan matahari berada dalam posisi hampir segaris sehingga kekuatan gravitasi dari bulan dan matahari saling memperkuat. Sedangkan tunggang pasut saat perbani, terjadi dengan posisi bulan, bumi, dan matahari membentuk sudut $90^{\circ}$, sehingga kekuatan gravitasi dari bulan dan matahari menjadi terbagi.

Periode terjadinya air pasang ke surut berikutnya ataupun air pasang ke pasang berikutnya dan air surut ke surut berikutnya sangat bervariasi. Periode saat pasut purnama, berdasarkan hasil perhitungan, tampak lebih teratur dari periode yang terjadi saat pasut perbani. Saat pasut purnama, periode yang dibutuhkan dari saat terjadinya pasang tertinggi ke surut terendah berikutnya umumnya terjadi selang waktu 6 sampai 7 jam. Untuk kasus yang sama saat umur bulan perbani, terjadi dalam periode waktu yang sangat bervariasi yaitu antara 1 sampai 16 jam. Demikian juga periode antara puncak pasang ke puncak pasang berikutnya dan surut terendah ke surut terendah berikutnya, saat pasut purnama lebih teratur dibandingkan dengan saat pasut perbani. Periode dari puncak pasang ke puncak pasang berikutnya saat pasut purnama kejadian terbanyak sekitar 12 jam dan surut terendah ke surut terrendah berikutnya sekitar 11 jam. Saat pasut perbani, periodenya sangat bervariasi antara 2 sampai 26 jam.

\section{Pengaruh Astronomis}

Pengaruh astronomisselain fase umur bulan adalah jarak benda langit terhadap bumi. Tentunya jarak benda langit juga mempengaruhi pasut di perairan bumi dimana semakin dekat jarak benda langit dengan bumi, maka semakin besar pengaruh yang ditimbulkan dan sebaliknya juga, semakin jauh benda langit dari bumi, semakin kecil pengaruh yang ditimbulkan. Pengaruh jarak pada perairan bumi dapat dilihat pada Tabel 1 dan 2 yang memuat tentang jarak matahari dekat dengan bumi yang disebut perihelion dan saat jauh dari bumi disebut aphelion yang dikaitkan dengan fase umur bulan, tunggang pasut dan muka laut rata-rata.

Jarak matahari saat dekat dengan bumi terjadi pada tanggal 2 Januari dan saat jauh dari bumi terjadi pada tanggal 2 Juli. Jarak matahari yang paling terdekat dengan bumi terjadi pada tahun 1995 dengan jarak 146.741 juta $\mathrm{km}$. Jarak tersebut tentu pengaruhnya jauh lebih besar dari pada tahun-tahun yang lain sehingga tunggang pasut yang dihasilkan sebesar 176,6 cm. Pengaruh dari jarak matahari dapat dilihat pada Tabel 1 . 
Tabel 1. Jarak matahari saat dekat dengan bumi (Perihelion).

\begin{tabular}{|c|c|c|c|c|c|}
\hline \multirow{2}{*}{ Tahun } & \multirow{2}{*}{$\begin{array}{c}\text { Jarak } \\
\text { (juta km) }\end{array}$} & \multirow{2}{*}{ Umur bulan } & \multicolumn{2}{|c|}{ Tunggang pasut (cm) } & \multirow{2}{*}{$\operatorname{MLR}(\mathrm{cm})$} \\
\hline & & & 1 & II & \\
\hline 1987 & 146.770 & 3 & 50,3 & 168,8 & 133,3 \\
\hline 1988 & 147.445 & 13 & 134,2 & 37,5 & 140,8 \\
\hline 1989 & 146.995 & 25 & 46 & 17 & 156,8 \\
\hline 1995 & 146.741 & 1 & 176,6 & 75 & 141,5 \\
\hline 2009 & 146.879 & 6 & 51.3 & 108,7 & 158,2 \\
\hline
\end{tabular}

Tabel 2. Jarak matahari saat jauh dari bumi (Aphelion).

\begin{tabular}{rccrrr}
\hline \multirow{2}{*}{ Tahun } & Jarak & Umur bulan & \multicolumn{2}{c}{ Tunggang pasut $(\mathrm{cm})$} & \multirow{2}{*}{ MLR $(\mathrm{cm})$} \\
\cline { 4 - 5 } & (juta km) & & \multicolumn{1}{c}{ I } & \multicolumn{1}{c}{ I } & \\
\hline 1987 & 151.893 & 7 & 104 & 39,5 & 137,7 \\
1988 & 152.423 & 19 & 44,9 & 145,1 & 149,5 \\
1989 & 151.747 & 28 & 35,7 & 154,7 & 152,8 \\
1995 & 151.797 & 5 & 111,1 & 56,2 & 150,1 \\
2009 & 152.260 & 11 & 12,7 & 96,8 & 148,5 \\
\hline
\end{tabular}

Pada Tabel 2 menunjukan ditahun 1988 terjadi Jarak matahari yang paling jauh dari bumi dengan jarak 152.423 juta $\mathrm{km}$ tetapi tunggang pasut yang dihasilkan pada jarak tersebut lumayan besar dengan nilai tunggang pasut yang pertama $44,9 \mathrm{~cm}$ sedangkan tunggang pasut yang kedua dengan nilai $145,1 \mathrm{~cm}$ karena pada hari tersebut didukung oleh faktor astronomis (fase umur bulan) yang berumur 19 hari (fase umur bulan purnama berjalan)

Kejadian jarak matahari serta pengaruh yang ditimbulkan yang diperlihatkan pada tabel 2 dan 3 menunjukan bahwa faktor astronomis (fase umur bulan) merupakan faktor utama dalam mempengaruhi pasut di perairan. Jadi, meskipun jarak benda langit berada jauh dari bumi namun ketika terjadi fase umur bulan 1 (bulan baru) atau fase umur bulan purnama akan menghasilkan nilai tunggang pasut yang besar sebaliknya, bila terjadi jarak matahari dekat dengan bumi akan tetapi pada saat itu bertepatan dengan umur bulan 7-8 (saat perbani), akan menghasilkan tunggang pasut yang kecil.

\section{Muka Laut Rata-Rata}

Pencarian Muka laut rata-rata bertujuan untuk milihat kondisi perairan suatu daerah apakah mengalami kenaikan atau perunan muka laut ratarat dari tahun ke tahun. Sama halnya dengan tunggang pasut, pencarian muka laut rata-rata juga menggunakan data pengukuran pasut dari tahun 1987 sampai tahun 2011. muka laut ratarata dilakukan beberapa pencarian seperti fluktuasi muka laut rata-rata harian untuk satu siklus umur bulan, fluktuasi muka laut rata-rata bulanan, dan fluktuasi muka laut rata-rata tahunan. Hasil pencarian tersebut disajikan dalam bentuk gambar.

Pada Gambar 5, ditampilkan variasi muka laut rata-rata menurut umur bulan dalam satu siklus penuh umur bulan di waktu yang berbeda. Berdasarkan grafik tersebut, tampak variasi muka laut rata-rata terkadang menampilkan bentuk yang hampir mirip dalam satu siklus umur bulan. Walaupun demikian, sebaliknya variasi muka laut rata-rata harian dapat menampilkan bentuk yang sangat berbeda antara satu siklus umur bulan dengan siklus umur bulan lainnya. 


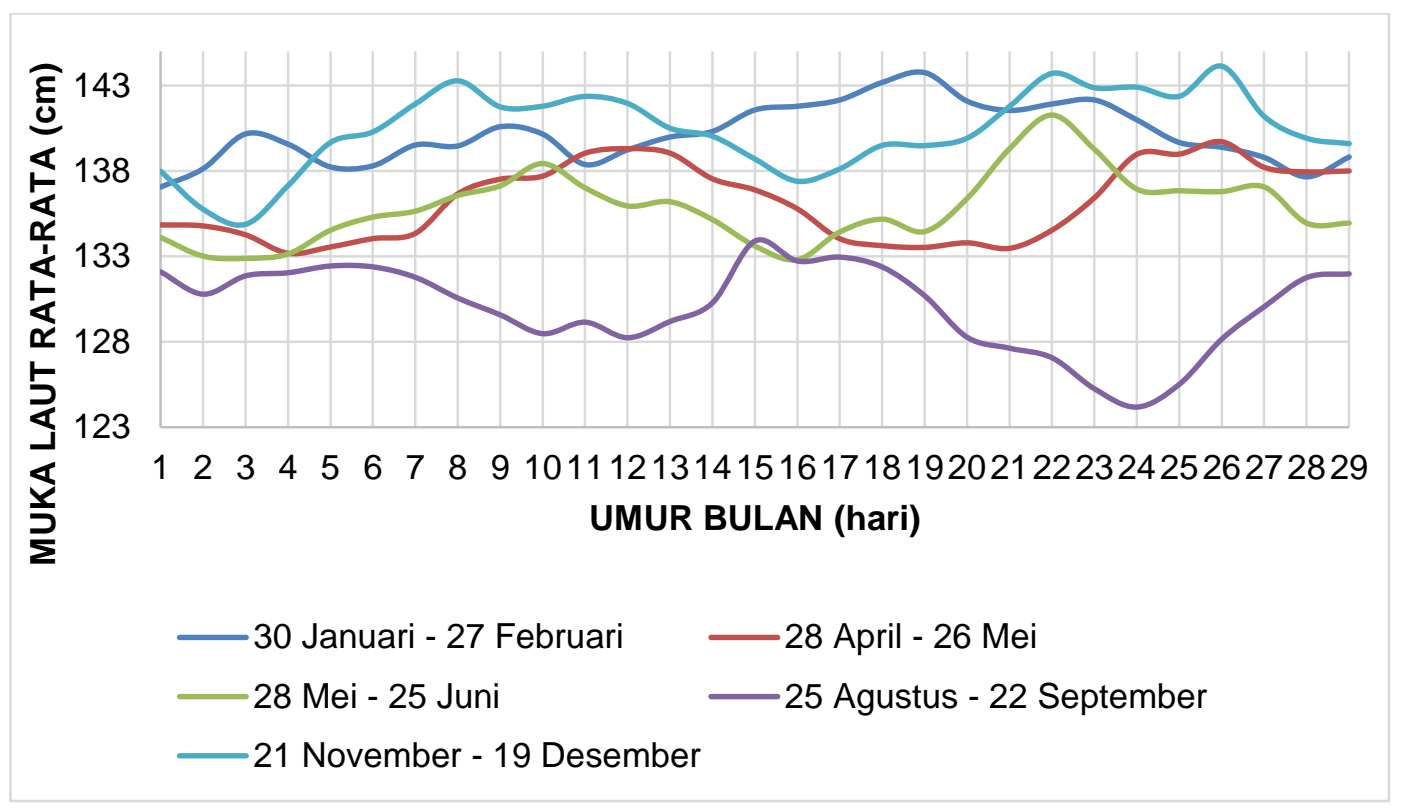

Gambar 5. Fluktuasi muka laut rata-rata beberapa siklus bulan pada tahun 1987.

Seperti yang diperlihatkan pada Gambar 5, grafik muka laut rata-rata menampilkan bentuk yang dapat dikatakan bertolak belakang antara satu siklus umur bulan dengan siklus umur bulan lainnya.

Muka laut rata-rata bulanan yang dimuat pada Gambar 6 secara jelas memperlihatkan bahwa fluktuasi muka laut rata-rata bulanan tahun 1987, 1989, dan 1990 berbeda dalam elevasinya. Perbedaan tinggi muka laut rata-rata bulanan yang terjadi kemungkinan dipengaruhi oleh tingginya tingkat curah hujan yang berbeda setiap tahunnya dan faktorfaktor lainnya seperti densitas air dan pergerakan massa air di perairan.

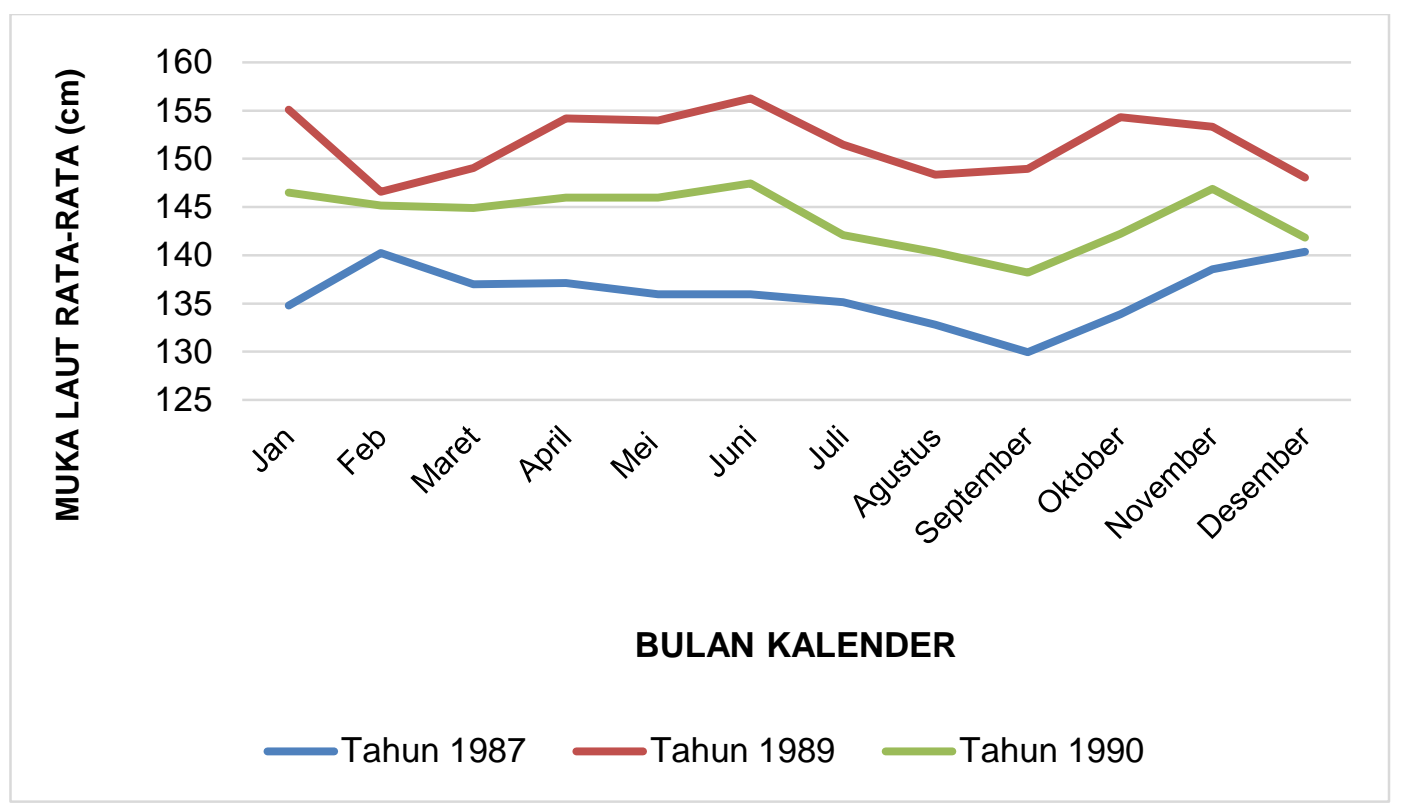

Gambar 6. Grafik fluktuasi muka laut rata-rata bulanan di perairan sekitar Samudera Bitung. 
Tabel 3. Muka laut rata-rata tahunan.

\begin{tabular}{ccc}
\hline \multicolumn{3}{c}{ MLR Tahunan } \\
\hline No & Tahun & MLR $(\mathrm{cm})$ \\
\hline 1 & 1987 & 139,5 \\
2 & 1988 & 149,1 \\
3 & 1989 & 154,2 \\
4 & 1990 & 144,8 \\
5 & 1992 & 140,2 \\
6 & 1994 & 144 \\
7 & 1999 & 149 \\
8 & 2000 & 149,2 \\
9 & 2008 & 155,4 \\
10 & 2009 & 152,9 \\
11 & 2010 & 156,9 \\
\hline
\end{tabular}

Pencarian muka laut rata-rata tahunan yang menggunakan data pengukuran dari tahun 1987 sampai 2010 didapatkan hasil bahwa perairan sekitar Kota Bitung Mengalami kenaikan. Hasil pencarian muka laut rata-rata tahunan telah dimuat ke dalam Tabel 3.

Pada tabel 3 memperlihatkan bahwa muka laut rata-rata tahunan mengalami perubahan dari ketinggian muka laut rata-rata tahunan. Pada tabel tersebut juga memperlihat bahwa muka laut rata-rata tahun 1987 merupakan muka laut rata-rata tahunan yang paling terendah sedangkan untuk muka laut paling tertinggi terdapat pada tahun 2010. Meskipun begitu dalam perjalan 1987 menuju tahun 2010, muka laut tahunan mengalami kenaikan dan penurunan ketinggian. Hal itu dibuktikan dengan data pada tahun 1987 menuju tahun 1989 mengalami kenaikan muka laut dengan selisi kenaikan antara muka laut rata-rata tahun 1987 dan 1989 adalah $14.6 \mathrm{~cm}$. Muka laut rata-rata tahunan terjadi penurunan kembali setelah 1989 menuju tahun 2010 Penurunan tersebut terjadi pada tahun 1990 dan 1992. Muka laut rata-rata tahunan bila dibandingkan antara muka laut ratarata terendah (tahun 1987) dan muka laut rata-rata tertinggi (tahun 2010), bahwa perairan di sekitar Kota Bitung mengalami kenaikan dengan selisi ketinggian $17.3 \mathrm{~cm}$.

\section{KESIMPULAN}

Bertolak dari hasil penelitian mengenai karakteristik non-harmonik pasut di perairan sekitar Kota Bitung, dapat disimpulkan bahwa Tunggang pasut terbesar setiap tahunnya dapat terjadi pada fase umur bulan baru maupun fase umur bulan penuh. Demikian juga, tunggang pasut terkecil dapat terjadi pada fase umur bulan perbani awal maupun perbani akhir. Terdapat indikasi tunggang pasut terbesar terjadi mendekati jarak bumi dan matahari berada pada posisi perigee. Variasi terhadap muka laut rata-rata tidak menunjukkan adanya keterkaitan dengan fase umur bulan. Hal tersebut dapat jelas dilihat pada kurva muka laut rata-rata harian yang berfluktuasi tidak mengikuti fase umur bulan.

\section{DAFTAR PUSTAKA}

Hwung, H.H. 2010. Utilization of The Coastal Area. Socioeconomic and Environmental Risk in Coastal and Ocean Engineering.In : Kim Y.C. (Ed) Handbook of Coastal and Ocean Engineering. World Scientific Publishing Co. Pte. Ltd. Singapore. 953 - 969 pp.

Lisnawati, L.A., Rochaddi, B., Ismunarti, D.W. 2013. Studi Tipe Pasang Surut di Pulau Parang Kepulauan Karimunjawa Jepara Jawa Tengah. Jurnal Oseanografi, 3: 214-220.

Losada, M.A., BaquerizoA., OrtegaSanchez, M., Santiago, J.M. 2010. Socioeconomic and Environmental Risk in Coastal and Ocean.In : Kim, Y.C. (Ed) Handbook of Coastal and Ocean Engineering.World Scientific Publishing Co. Pte. Ltd. Singapore. 923 - 952 pp.

Pariwono, J.I. 1989. Pasang Surut :Kondisi Pasang Surut di Perairandalam :Ongkosongo, 
O.S.R., Suyarso. (Editor) Lembaga IImu Pengetahuan Indonesia, Pusat Penelitian dan Pengembangan Oseanologi. Jakarta. Hal 135 - 147.

Pugh, D., Woodworth, P. 2014. SeaLevel Science : Understanding Tides, Surges, Tsunami, and Mean Sea Level. Second Edition. Cambridge University Press. United Kingdom. p 395.

Stewart, H.R. 2008. Introduction to Physical Oceanograph Department of Oceanography. A \& M University. Texas. p 345.

Thorpe, S.A. 2009. Elements of Physical Oceanography. A Derivative of Encyclopedia of Ocean Sciences, Second Edition. Elsevier. London. p 647. 